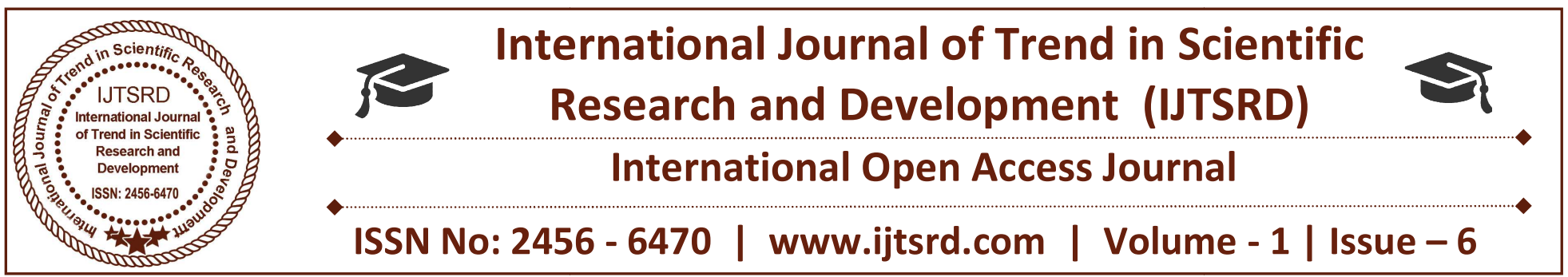

\title{
Morphometric Analysis of Kabini River Basin in H.D.Kote Taluk, Mysore, Karnataka, India
}

\author{
Gangadhara G \\ Research scholar, Department of Studies in Geography, Manasagangotri University of Mysore
}

\begin{abstract}
Morphometric analysis becomes important when watershed development and Management plans are taken into consideration. Morphometric analysis was carried out on kabini river basin using topographic maps on a scale map of 1:50,000 to determine its drainage characteristics. Remote sensing and GIS tools have proved to be an efficient tool in this study in drainage delineation and calculation of some of the aerial and linear parameters. The drainage pattern of the basin.
\end{abstract}

Keywords: Morphometric, stream order, GIS and remote sensing

\section{INTRODUCTION}

Hydrogeomorphology has been defined as "an interdisciplinary science that focuses on the interaction and linkage of hydrologic processes with landforms or earth materials and the interaction of geomorphic processes with surface and subsurface water in temporal and spatial dimensions." Geomorphologic structure and drainage patterns especially in hard rock Terrains are the primary determinants of river ecosystem functioning at the basin scale Understanding the drainage pattern of an area gives a perspective view of the topography of the area which helps in the planning and development of water sheds and also provides an indication of the potential zones for obtaining ground water. Morphometric techniques are applied for interpretation of silent features of drainage networks. It incorporates a quantitative study of the area, its altitude, volume, slope, profiles of land and the drainage basin characteristics of the concerned area.

\section{Objectives}

To study the drainage characteristics of kbini river basin in the study area

To evaluate the hydrological conditions in all watersheds of the study area 


\section{Study Area}

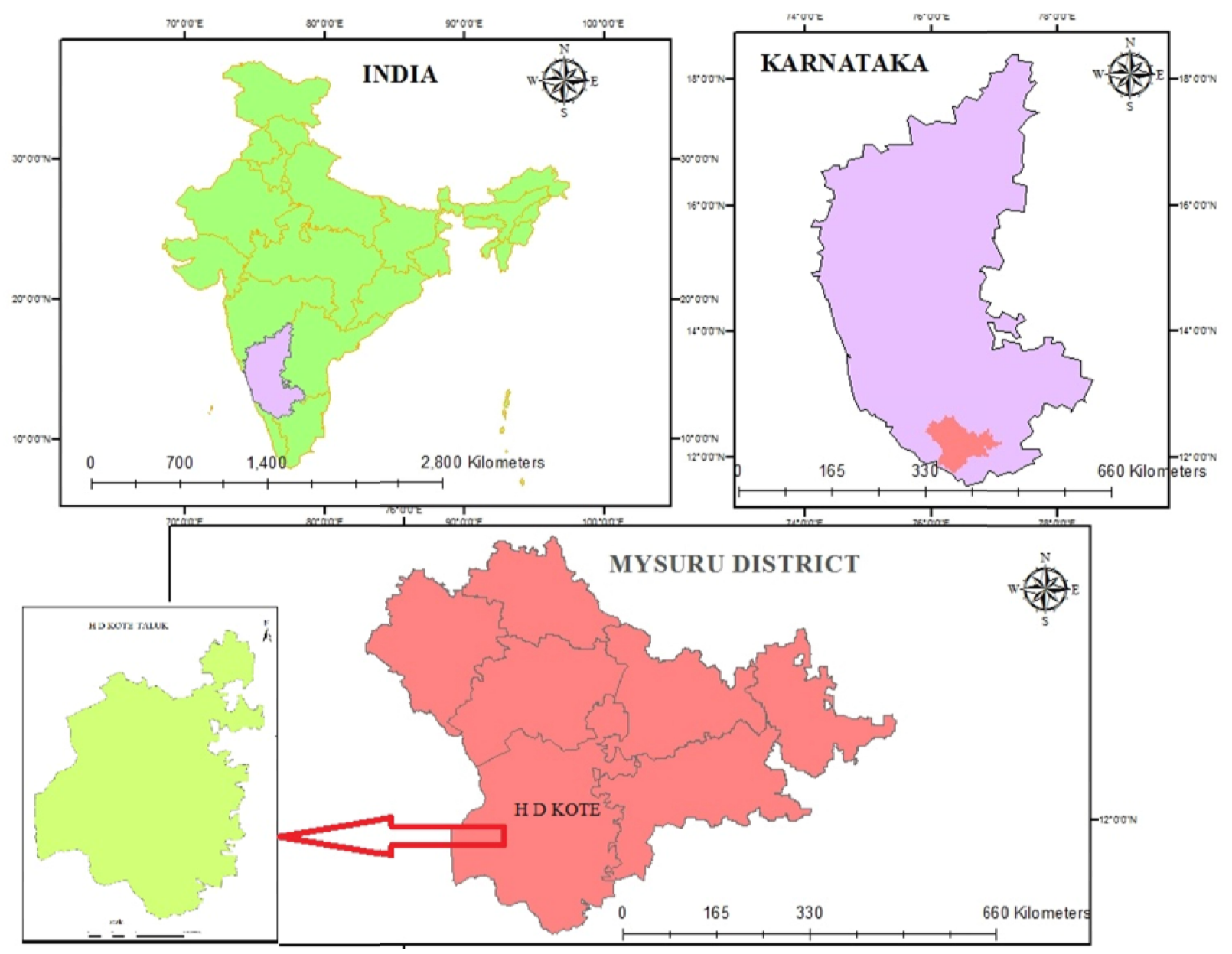

The kabini (kapila) river originated in northern wynad regions of Kerala at an elevation of 2140 meters.it had a length $230 \mathrm{~km}$, drainage areas $7808 \mathrm{~km} 2$ it is a perennial river. The kabini (kapila) river, a tributary to Cauvery river, These river basin located between $11^{\circ}$

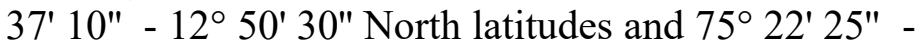
$76^{\circ} 58^{\prime} 02^{\prime \prime}$ East longitudes. Covered under the Survey of India Toposheet numbers are $57 \mathrm{D} / 7,57 \mathrm{D} / 11$, $57 \mathrm{D} / 4,57 \mathrm{D} / 8,57 \mathrm{D} / 12,58 \mathrm{~A} / 1,58 \mathrm{~A} / 5$ and $58 \mathrm{~A} / 6$ on scale of $1: 50,000$. H.D.Kote taluk is an undulating land with igneous and metamorphic rocks of Precambrian age. The study area forms the southern part of the Mysore district. The general elevation of the Area ranges from 700-950 meters AMSL. The mountain ranges in the study area originate from the Nilgiri hills along its southern borders and runs in northwest and northeast direction. The study area is almost entirely surrounded by Western Ghats, which at places are on the elevation of more than 1200 meter AMSL.

The climate of the area may be described as essentially tropical monsoon type which is a product of the interplay of the two opposing air-masses of the southwest and northeast monsoons. Summers are languorously warm and winters bracingly cool. By and large the area is endowed with a delightful or salubrious climate and hence the region faces shortage of water in dry seasons.

\section{MATERIAL AND METHODS}

Morphometric analysis is quantitative description and analysis of landforms as practiced in geomorphology that may be applied to a particular kind of landform or to drainage basin and large regions generally. Morphometric analysis of The kabini river basin was carried out on the toposheets in the scale of 1:50000.The toposheets were first georeferenced with UTM projection system by arc GIS 10.5In this paper the analysis have been grouped into five categories: basic parameters, 2) derived parameters, 3) shape parameters 4) dissection intensity parameters and 5) height parameters. All the parameters have been discussed in detail. 


\section{MORPHOMETRIC ANALYSIS}

Morphometry is the measurement and mathematical analysis of the configuration of the Earth's surface, shape and dimensions of the landforms This analysis can be done through measurement of linear, Aerial and Relief aspects of basin and slope delineation In the present study, the morphometric analysis for the parameters namely stream order, stream length, bifurcation length, stream length ratio, basin length, drainage density, stream frequency, elongation ratio, circulatory ratio, form factor and relief ratio have been carried out. This study has been carried out with respect to sub watersheds which have been recognized in the main watershed. The three sub watersheds are Taraka, Kabini and Nuguhole. The drainage network show dendritic to sub-dendritic patterns.

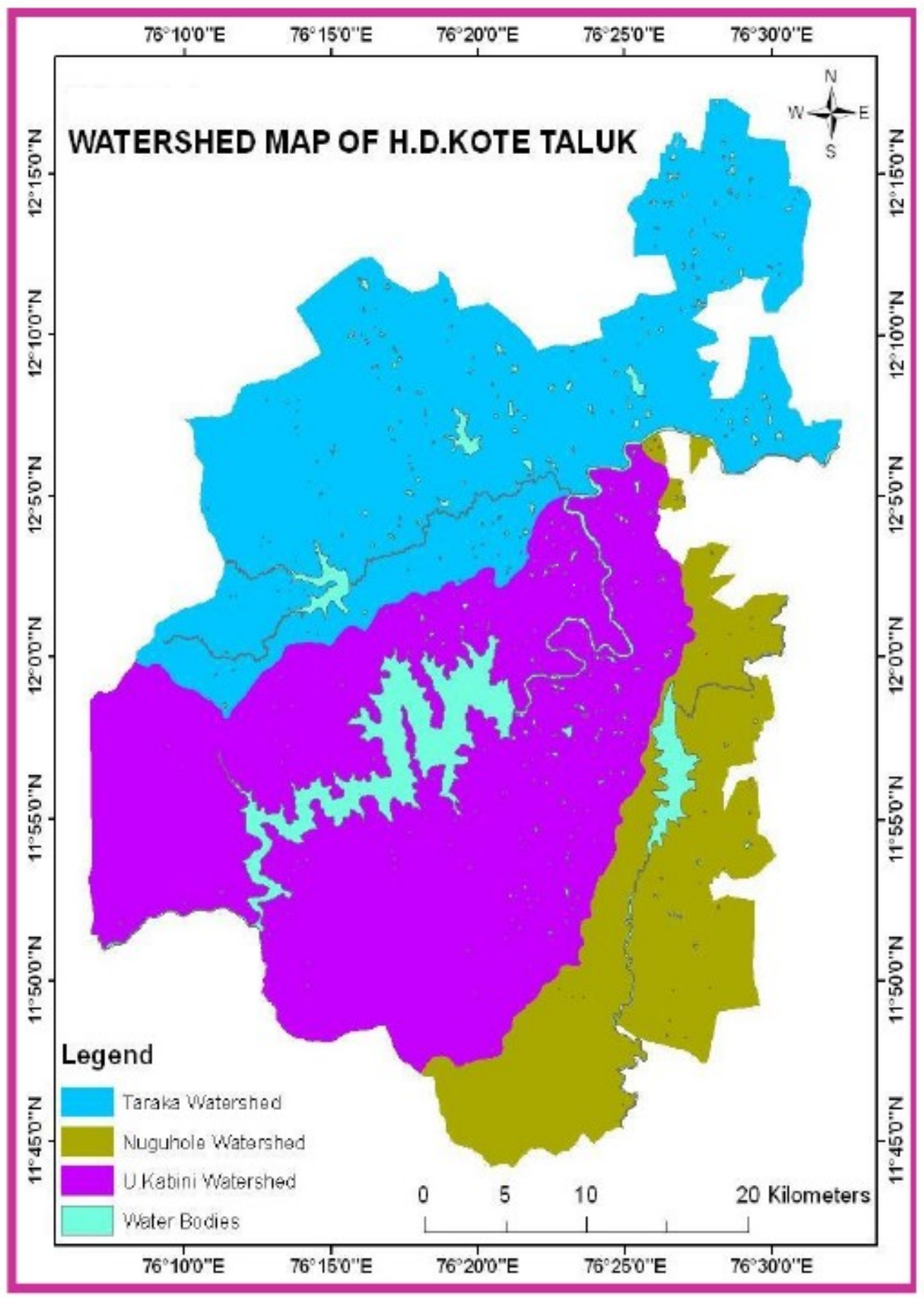

Sources (sodhganga) 


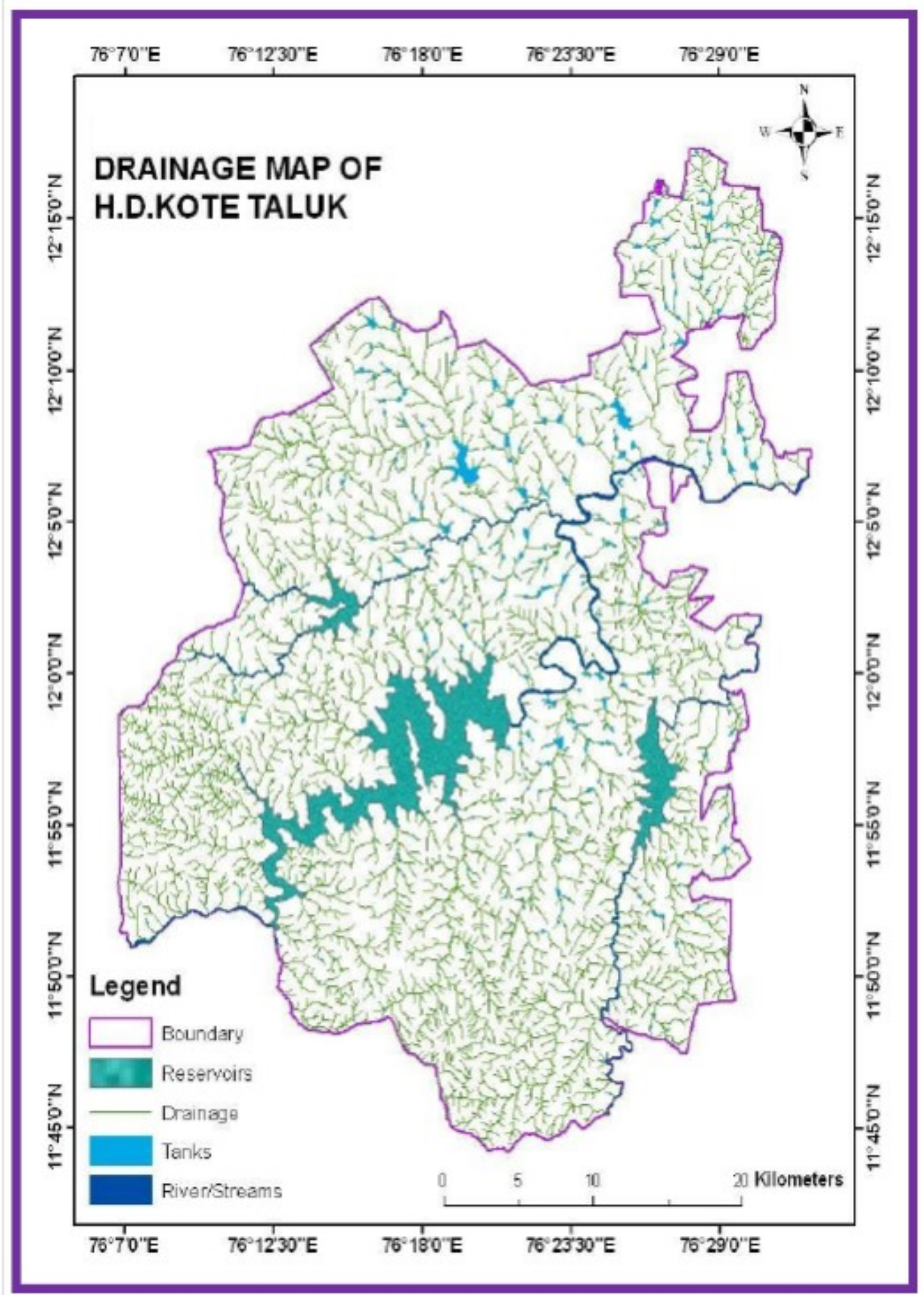

Sources (shodh ganga) 
International Journal of Trend in Scientific Research and Development (IJTSRD) ISSN: 2456-6470

\section{RESULTS AND DISCUSSION}

\section{Results of Morphometric analysis of three sub-watershed of the study area}

\begin{tabular}{|c|c|c|c|c|c|c|c|c|c|c|c|c|c|c|c|c|c|c|}
\hline \multirow{2}{*}{$\begin{array}{l}\text { S. } \\
\text { no }\end{array}$} & \multirow{2}{*}{$\begin{array}{c}\text { Name of the } \\
\text { Basin }\end{array}$} & \multirow{2}{*}{$\begin{array}{c}\text { Stream } \\
\text { order }\end{array}$} & \multicolumn{7}{|c|}{ Stream number in different Orders } & \multirow{2}{*}{ (Nu) } & \multicolumn{7}{|c|}{ Order wise total stream length } & \multirow{2}{*}{ (Lu) } \\
\hline & & & $\mathbf{i}$ & ii & iii & iv & $\mathbf{v}$ & vi & vii & & $\mathbf{i}$ & ii & iii & iv & $\mathbf{v}$ & vi & vii & \\
\hline 1 & TARAKA & vii & 816 & 301 & 84 & 32 & 16 & 9 & 4 & 1262 & 323.5 & 144 & 56.5 & 27 & 10.5 & 6.5 & 6.5 & 574.5 \\
\hline 3 & NUGUHOLE & vi & 315 & 98 & 40 & 11 & 4 & 4 & $\ldots$ & 472 & 135 & 50 & 31 & 9.5 & 7 & 4 & $\ldots$ & 236.5 \\
\hline
\end{tabular}

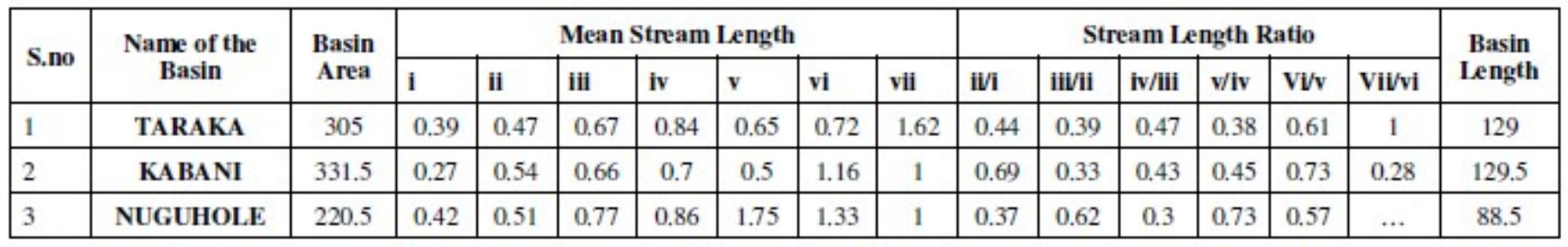

\begin{tabular}{|c|c|c|c|c|c|c|c|c|c|c|c|c|c|c|c|}
\hline \multirow{2}{*}{ S.no } & \multirow{2}{*}{$\begin{array}{c}\text { Name of the } \\
\text { Basin }\end{array}$} & \multicolumn{6}{|c|}{ Bifurcation Ratio (Rb) } & \multirow{2}{*}{ Rbm } & \multirow{2}{*}{ Dd } & \multirow{2}{*}{ Fs } & \multirow{2}{*}{ Rf } & \multirow{2}{*}{$\operatorname{Re}$} & \multirow{2}{*}{$\mathbf{R c}$} & \multirow{2}{*}{ Rt } & \multirow{2}{*}{ Lg } \\
\hline & & i/ii & ii/iii & iii//v & iv $/ \mathbf{v}$ & $\mathrm{v} / \mathrm{vi}$ & vi/vii & & & & & & & & \\
\hline 1 & TARAKA & 2.71 & 3.58 & 2.62 & 2 & 1.77 & 2.25 & 2.57 & 1.88 & 4.13 & 0.01 & 0.15 & 0.04 & 4.13 & 1.06 \\
\hline 3 & NUGUHOLE & 3.21 & 2.45 & 3.63 & 2.75 & 1.33 & 3 & 2.22 & 1.07 & 2.14 & 0.02 & 0.18 & 0.05 & 2. 14 & 1.86 \\
\hline
\end{tabular}

Sources ( shodhganga Nagrag D et al)

\section{CONCLUSION}

The H.D.Kote taluk sub river basin level has been carried the hydrological boundary into consideration The area has been divided into three sub-basins. Kabini river in around H D kote tq is found to be fifth order, the stream length ratio of the sub basin and its watersheds are changing randomly which is attributed due to differences in slope and topographic conditions of the study area. The bifurcation ratio varies from one order to its next order. These irregularities are

dependent upon the geological conditions of the drainage basin. The lower values are characteristics of the taluk, which have suffered less structural

disturbances, and the higher values indicate strong structural control on the drainage

pattern. Drainage density values of the sub-basin and the watersheds are all indicative of very uncouth to drainage texture which is having highly permeable subsoil, dense vegetative cover and low relief. All the three shape parameters elongation ratio, circularity ratio and form factor are suggestive of an elongated shape for the basin, in turn has an effect on the discharge characteristic of the basin. The higher values of relief ratio and relative relief values are indicative of basin located in the south-western part of the sub-basin Having steeper slope and high relief compare the remaining watersheds having lower to gentle slope values.

\section{REFERENCES}

1) Lotspeich FB and Platts WS, An integrated landaquatic classification system. $N$ Am $J$ Fish Manage 2, 138-149, (1982)

2) Savindra Singh, Geomorphology, Prayag Pustak Bhawan, Allahabd, 358 Fifth revoised, (2007)

3) Geological Society of India, Anuual report, Bangalore, (2007)

4) Strahler AN, Quantitative geomorphology of drainage basin and channel networks. In: Chow VT (ed) Handbook of applied hydrology. McGraw Hill Book Co., New York, 4- 76, (1964)

5) Horton RE, Erosional development of systems and their drainage basins. Hydrophysical approach to quantitative morphology . Geol Soc Am Bull, 56(3), 275-370, (1945)

6) Horton RE, Drainage basin characteristics. Trans Am Geophys Union. 13, 350-361, (1932) 
7) Srtahler AN, Hypsometric (areaaltitude) analysis of erosional tpography. Bull Geolo Soc Am 63,1117-1142, (1952)

8) Schummm, Evolution of drainage systems and slopes in Badlands at Perth Amboy, New Jersey, Natl Geol Soc Am Bull 67, 597-646, (1956)

9) Smith KG, Erosional processes and landforms inn Badlands national monument South Dakota Bull GeolSoc 69, 975-1008, (1950)

10) Melton MA, Geometric properties of mature drainage system and therir representation in an E4 phases space.

11) J.Geol, 66, 35-54, (1958)P.D. Sreedevi, K.Subrahmanyam and S. Ahmed, The significance ofmorphometric analysis for obtaining groundwater potential zones in a structurally controlled terrain, Environmental Geology, 47, 412-420,(2004)

12) Singh S and Singh MC, Morphometric analysis of Kanhar river basin. National geophysical.J. of India, 43(1), 31-43, (1977)

13) Chow Ven $T$ (ed), Handbook of applied hydrology. McGraw Hill Inc. New York, (1964)

14) Miller VC, A quantitative geomorphic study of drainage basin characteristics in the Clinch
Mountain area, Virginia and Tennessee, Technical report, 3, Department of Geology, Columbia University, New York, (1953)

15) Gregory KJ, Walling De, Drainage basin form and process, geomorphological approach, Wiley, New York,456 (1973)

16) Verstappen H, The applied geomorphology. International Institute for Aerial Survey and Earth Science (I.T.C), Enschede, The Netherlands, Amsterdam, Oxford, New York, (1983)

17) Hadely RF, Schumm SA, Sediment sources and drainage basin characteristics in upper Cheyenne River Basin. U.S Geological Survey Water-Supply paper 1531-B, 198, (1961)

18) Gottschalk LC, Reservoir sedimentation. T.Chow(ed), Handbook of applied hydrology. McGraw Hill Book Company, New York, Section 7- 1, (1964)

19) Fernandez HR, Molineri C. Toward a sustainable experience in an intermountain valley from northwestern of Argentina, (2006)

20) mohamed and nagraj d "applications of remote sensing and gis for selecting artificial recharge zones in h.d.kote taluk, mysore district, karnataka, india". 